and Dr. H. E. Magee, of the Ministry of Health (Medical Secretary).

\section{National Baby Week}

THe National Baby Week Council, 117 Piccadilly, London, W.1, has issued its report for 1934. The propaganda subject for the year was "The Making of an A 1 Nation", and special propaganda dealt with "The Diet of the Expectant Mother" and "Food and Feeding". National Baby Week is to be held this year on July 1-7, and the special subjects suggested for consideration are "The Welfare of the Pre-School Child" and "Good Nutrition of Mothers and Children". A poster competition is arranged for boys and girls of 'senior schools', and prizes are offered to parents for the best essays on one of two subjects: "What should be done were there an Outbreak of Diphtheria", and "On the Effect of Overcrowding on the Welfare of Mothers and Little Children". The Council will gladly advise and give help on propaganda work, the choice of subjects for lectures, etc., and on other matters relating to infant welfare.

\section{South-Eastern Union of Scientific Societies}

THE fortieth Annual Congress of the South-Eastern Union of Scientific Societies will be held at Bournemouth on June 26-29, under the presidency of Prof. A. C. Seward. On June 26, Prof. Seward will deliver his presidential address entitled "The Herbarium of the Rocks". Prof. J. Cameron will deliver a public lecture on June 27 at 8, entitled "Egyptology"; and Lieut.-Colonel C. D. Drew will deliver a public lecture on June 28, at 8, entitled "Recent Excavations at Maiden Castle". The following sectional presidential addresses are announced: Archæological Section (Mr. T. D. Kendrick), "Early Christian Art in the British Isles"; Botanical Section (Prof. H. J. Tabor), "Effects of Certain Physical Factors on the Determination of Plant Habitat" ; Zoological Section (Rev. F. C. R. Jourdain), "Zoological Progress during the last Half-Century, with special reference to Ornithology" ; Geological Section (Dr. H. D. Thomas), "Some Aspects of Evolution"; Regional Survey Section (Dr. Vaughan Cornish), "Scenic Amenities in Town and Country". Further information can be obtained from the Honorary General Secretary, Mr. Edward A. Martin, 14 High View Close, Norwood, London, S.E.19.

\section{Announcements}

At a meeting on April 27, the Leeuwenhoeck Gold Medal of the Royal Academy of Sciences, Amsterdam, was awarded to Prof. S. N. Winogradsky, foreign associate of the Academy and also a foreign member of the Royal Society, who is director of the Division of Agricultural Microbiology of the Institut Pasteur, Brie-Comte-Robert, France, for his outstanding contributions to the development of soil microbiology. The medal is awarded decennially to commemorate the discovery of micro-organisms by Antony van Leeuwenhoeck. Previous recipients of the medal have been : C. G. Ehrenberg, Ferd. Cohn, L. Pasteur, M. W. Beijerinck, Sir David Bruce and F. d'Hérelle.
Dr. Wesley Bourne, of Montreal, has been awarded the first Hickman Medal of the Royal Society of Medicine. Dr. Bourne is anæsthetist to the Royal Victoria Hospital, Montreal, and also lecturer in pharmacology in McGill University. $\mathrm{He}$ is well known to many anæsthetists in Great Britain, both personally and for his researches into the physiology and pharmacology of anæsthesia.

Sir Frederick Hobday will deliver the Stephen Paget Memorial Lecture on the occasion of the annual general meeting of the Research Defence Society on June 12 at 3 , in the London School of Hygiene and Tropical Medicine, Keppel Street, W.C.1, taking as his subject "The Relief of Animal Suffering".

THE Walter Rathbone Bacon Travelling Scholarship of the Smithsonian Institution has been awarded to Dr. Richard E. Blackwelder, now engaged in entomological work at the U.S. National Museum, for an intensive study of the staphylinid beetles of the West Indies. Dr. Blackwelder will collect these curious little beetles, which are distinguished from other families of beetles by their short wing covers, although nearly all have normally large wings and most of them are good flyers, on twenty-five West Indian Islands, including Cuba, Hispaniola, Puerto Rico and Jamaica. After completing his collections in the West Indies, Dr. Blackwelder will study the large collections in the British Museum.

Applications are invited for the following appointments, on or before the dates mentioned :--Three University lecturers and one demonstrator in the University of Cambridge-Mr. H. Thirkill, Clare College, Cambridge (June 10). A lecturer in mechanical engineering in the West Hartlepool Technical College-The Secretary for Education, Education Offices, West Hartlepool (June 14). A head of the Science Department, Central Polytechnic, Croydon-The Education Officer, Education Office, Katherine Street, „Croydon (June 15). A lecturer in physiology in the University of Bristol-The Registrar (June 19). A lecturer in physics and mathematics in the Northampton Polytechnic, St. John Street, London, E.C.1-The Principal (June 21). Geologists on the Geological Survey of Great Britain and the Museum of Practical Geology, Exhibition Road, South Kensington, S.W.7 -Director (June 21). A lecturer in physics in the Constantine Technical College--The Director of Education, Education Offices, Middlesborough (June 22). A head of the Chemistry Department in the Rutherford Technical College-The Director of Education, City Education Office, Northumberland Road, Newcastleupon-Tyne, 2 (June 22). An assistant lecturer in agricultural botany in the South-Eastern Agricultural College, Wye, Kent-The Secretary (June 22). A temporary lecturer in geography in Armstrong College, Newcastle-upon-Tyne-The Registrar (June 25). Two research workers at the research laboratory of the Freshwater Biological Association of the British Empire, Wray Castle, Ambleside, Westmorland-The Naturalist-in-Charge (July 1). 